\title{
PERSISTENCE OF ACETOLACTATE SYNTHASE INHIBITING HERBICIDES IN A CANTERBURY SOIL
}

\author{
RICHARD W. McDOWELL ${ }^{1}$, FARHAD DASTGHEIB ${ }^{2}$ \\ and LEO M. CONDRON ${ }^{1}$
}

\author{
Department of Soil Science ${ }^{1}$ and Department of Plant Science ${ }^{2}$ \\ P.O. Box 84, Lincoln University, Canterbury
}

\begin{abstract}
The degradation of imazapyr, flumetsulam and thifensulfuron applied at 500, 40 and $30 \mathrm{~g} /$ ha respectively to a silt loam soil was studied under laboratory conditions. Herbicide residues were analysed by a lentil (Lens culinaris) bioassay. Results showed that temperature had a significant effect on herbicide degradation, while the impact of soil organic matter and $\mathrm{pH}$ were less well defined. Half-lives for imazapyr, flumetsulam and thifensulfuron in the soil with low organic carbon $(3.5 \%)$ at $15^{\circ} \mathrm{C}$ were 155,70 and 6.4 days respectively and 77,24 and 4.8 days at $30^{\circ} \mathrm{C}$. In the soil with high organic carbon $(6.4 \%)$ half-lives were 125,88 and 5.4 days respectively at $15^{\circ} \mathrm{C}$ and 69,30 and 3.8 days at $30^{\circ} \mathrm{C}$.
\end{abstract}

Keywords:Imazapyr, flumetsulam, thifensulfuron, bioassay, herbicide degradation

\section{INTRODUCTION}

Agrochemical management requires careful consideration of many factors in order to provide the desired efficacy without exhibiting adverse agronomic effects. Preventing the build-up of herbicides to phytotoxic levels requires detailed knowledge of the persistence of residues under a variety of soil conditions. Herbicides based on the inhibition of acetolactate synthase (ALS) have been shown to vary widely in their degradation rates in response to soil $\mathrm{pH}$, organic matter content and temperature (James et al. 1989; Lehmannet al. 1993). Thifensulfuron, flumetsulam, and imazapyr are representatives of the sulfonylurea, triazolopyrimidine sulfonanilide and imidazolinone classes of ALS herbicides respectively. Imazapyr has been used in New Zealand for some years, while thifensulfuron and flumetsulam have only recently been registered. The objective of the present study was to determine the persistence of thifensulfuron, flumetsulam and imazapyr at two different temperatures in a Templeton silt loam soil taken from different depths using a bioassay proceedure.

\section{Herbicides}

\section{MATERIALS AND METHODS}

The herbicides used were commercial formulations of thifensulfuron (Harmony $750 \mathrm{~g} / \mathrm{kg}$ D.F.), flumetsulam (Preside $800 \mathrm{~g} / \mathrm{kg} \mathrm{D.F.),} \mathrm{and} \mathrm{imazapyr} \mathrm{(Arsenal} 250 \mathrm{~g} /$ 1 W.S.C.) applied at 30,40 and $500 \mathrm{~g} /$ ha respectively in the laboratory incubation experiment.

\section{Soil}

Soil used for the laboratory incubation experiment comprised two depth increments $(0-5$ and $15-20 \mathrm{~cm})$ of a Templeton silt loam (Udic Ustochrept) taken from a site at the Henley Block, Lincoln University. The $0-5 \mathrm{~cm}$ soil was designated as 'high' organic matter (6.4\% organic carbon [C]) and the $15-20 \mathrm{~cm}$ soil was designated as 'low' organic matter (3.5\% organic C). Initial soil analysis included $\mathrm{pH}$ (water) and Tamm oxalate extractable amorphous iron and aluminium (Blakemore et al. 1987). 


\section{Bioassay development}

Preliminary experiments were conducted on the Templeton soil (mixture of 0-5 and $15-20 \mathrm{~cm}$ ) using lentil (Lens culinaris), maize (Zea mays), rapeseed (Brasica napus), and turnip (Brasica rapa). Lentil (var. 'Taitori') was found to be the most susceptible species. The final bioassay procedure for the lentil root length response curve used four replicates of each herbicide at seven different rates (Fig. 1). The mass of herbicide required $\left(2 \mathrm{~cm}\right.$ depth, bulk density of $\left.1.1 \mathrm{~g} / \mathrm{cm}^{3}\right)$ was dissolved in $100 \mathrm{ml}$ of water and applied to $2 \mathrm{~kg}$ of moist (60\% field capacity) soil. The herbicide-soil mixture was then placed in a plastic bag and shaken for 2 minutes and allowed to equilibrate overnight. Sub-samples of soil were then packed gently into square petri dishes $(100 \times 100 \times 20 \mathrm{~mm})$, and 3 pre-germinated lentils were imbedded at the top of the dish. Root tips were then marked on the petri dish, the dish sealed with plastic clingfilm, and incubated at $23^{\circ} \mathrm{C}$ in the dark. Measurements of root growth were then taken at 4 hourly intervals between 24 and 96 hours after planting.

\section{Laboratory incubation}

Herbicide (imazapyr $500 \mathrm{~g} / \mathrm{ha}$; flumetsulam $40 \mathrm{~g} / \mathrm{ha}$; thifensulfuron $30 \mathrm{~g} / \mathrm{ha}$ ) was applied to the soil $(60 \%$ field capacity, $<2 \mathrm{~mm})$ and four replicate samples were aerobically incubated at 15 and $30^{\circ} \mathrm{C}$. Sub-samples of each replicate were taken 1,2 , $3,4,6,8,10,12$, and 14 weeks after herbicide application and analysed for herbicide residues using the lentil bioassay described above. At the cessation of the laboratory incubation, soil from each treatment was analysed for microbial biomass $\mathrm{C}$ according to the method of Voroney et al. (1993).

\section{Bioassay}

\section{RESULTS AND DISCUSSION}

Results for the bioassay lentil root length response curve 72 hours after herbicide application are shown in Fig. 1. Data for all other 4 hourly intervals exhibited either greater variability or less sensitivity and hence are not presented. All subsequent

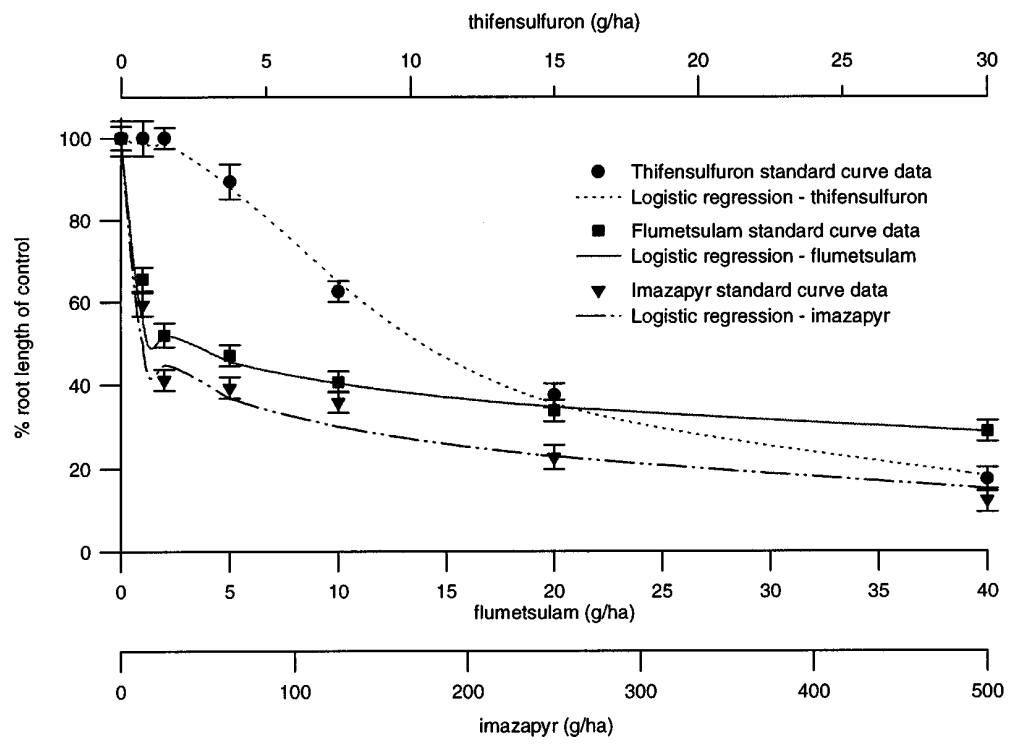

FIGURE 1: Bioassay standard curve of the effect of thifensulfuron, flumetsulam, and imazapyr on lentil root growth $[ \pm$ S.E.M. (I)] after 72 hours. 
bioassays were therefore determined after 72 hours. The shape of the lentil root length response curves were similar for imazapyr and flumetsulam, with a sharp decline in root lengths over a limited range of low concentrations. The greatest sensitivity shown by the imazapyr, flumetsulam and thifensulfuron curves was between 10-50, 1-10 and 3-17 g/ha, respectively. A detection limit of $3 \mathrm{~g} / \mathrm{ha}$ were established for thifensulfuron, while limits of $1 \mathrm{~g} / \mathrm{ha}$ and $12.5 \mathrm{~g} / \mathrm{ha}$ were established for flumetsulam and imazapyr respectively. Levels of thifensulfuron below the detection limit appeared to stimulate lentil growth. A four parameter logistic model gave good agreement with the experimental data, estimating model parameters to within a $95 \%$ level of tolerance.

\section{Laboratory incubation}

The first order kinetic model used to calculate half-life $\left(\mathrm{t}_{1 / 2}\right)$ estimated parameters to within $95 \%$ of the observed data. Thifensulfuron degraded rapidly at both temperatures (3.9-6.4 days), while the half lives for flumetsulam (24.1-87.9 days) and imazapyr (68.6-155.4 days) were much longer (Table 1). As expected, degradation rates were faster at $30^{\circ} \mathrm{C}$ compared with $15^{\circ} \mathrm{C}$ in both soils. The effect of organic matter on herbicide degradation was less pronounced. In both the imazapyr and thifensulfuron treated soils the rate of degradation was faster in the low organic matter soil compared with the higher organic matter soil, however the opposite trend occurred in the flumetsulam treated soils (Table 1). Microbial biomass carbon was greatest in the higher organic matter soils of all treatments except imazapyr at $30^{\circ} \mathrm{C}$ and flumetsulam at both temperatures (Table 1). It was also higher in imazapyr treated soils at $30^{\circ} \mathrm{C}$ than at $15^{\circ} \mathrm{C}$, which may partially account for the reduced half-life of imazapyr at $30^{\circ} \mathrm{C}$, although the inherent variability make conclusions concerning microbial biomass $\mathrm{C}$ difficult.

TABLE 1: Half lives and mean microbial biomass $C( \pm$ standard error of the mean [SEM]) for three herbicides, at two temperatures in soil with low and high organic matter contents.

\begin{tabular}{ccccc}
\hline Herbicide & $\begin{array}{c}\text { Incubation } \\
\text { temperature } \\
\left({ }^{\circ} \mathrm{C}\right)\end{array}$ & $\begin{array}{c}\text { Soil organic } \\
\text { matter }\end{array}$ & $\begin{array}{c}\mathrm{t}_{1 / 2} \\
(\text { days })\end{array}$ & $\begin{array}{c}\text { Microbial } \\
\text { biomass carbon } \\
(\mu \mathrm{g} \mathrm{C} / \mathrm{g} \text { soil })\end{array}$ \\
\hline imazapyr & 15 & low & $155.4 \pm 9.9$ & $376 \pm 127$ \\
& 15 & high & $124.7 \pm 8.5$ & $622 \pm 60$ \\
flumetsulam & 30 & low & $76.8 \pm 8.7$ & $1233 \pm 276$ \\
& 30 & high & $68.6 \pm 9.3$ & $1161 \pm 170$ \\
& 15 & low & $69.8 \pm 2.1$ & $1298 \pm 351$ \\
thifensulfuron & 15 & high & $87.9 \pm 1.5$ & $1286 \pm 349$ \\
& 30 & low & $24.1 \pm 1.6$ & $154 \pm 64$ \\
& 15 & high & $29.5 \pm 1.4$ & $74 \pm 155$ \\
& 15 & low & $6.4 \pm 2.1$ & $88 \pm 82$ \\
Untreated soil & 30 & high & $5.4 \pm 1.1$ & $1090 \pm 45$ \\
& 30 & low & $4.8 \pm 1.9$ & $134 \pm 79$ \\
& - & high & $3.9 \pm 1.3$ & $864 \pm 101$ \\
& - & low & - & $460 \pm 135$ \\
& & high & - & $840 \pm 127$ \\
\hline
\end{tabular}

Differences in $\mathrm{pH}$ between the low and high organic matter soils (5.9 and 6.4 respectively) may have influenced herbicide degradation (Cambon and Bastide 1992). In retrospect it may have been wise to isolate the effect of organic matter by increasing the $\mathrm{pH}$ of the high organic matter soil (to 6.4). The fact that both soils contained similar low levels of amorphous $\mathrm{Fe}$ and $\mathrm{Al}$ oxides $(0.54-0.56 \% \mathrm{Fe}, 0.23 \% \mathrm{Al})$ (Blakemore $e t$ al. 1987) suggests that mineral sorption was not a significant factor in determining differences in herbicide degradation between soils. It should be noted that 'half-life' obtained using a bioassay may be defined as "the time taken for the amount of 
herbicide in the 'plant-available' pool to equal half of the total herbicide applied". The present study showed that at both temperatures, half-lives of imazapyr (and thifensulfuron) were inversely related to soil organic matter content (Table 1). While these results may reflect differences in $\mathrm{pH}$ and microbial biomass $\mathrm{C}$, the reduced biological activity detected (and hence the half-life) in the higher organic matter soil may be due to enhanced sorption onto soil organic constituents (Sims et al. 1992).

\section{ACKNOWLEDGEMENTS}

Funding for this project was provided by the New Zealand Plant Protection Society. We would also like to thank Mr Roger Cresswell and Mr Bruce Main for assistance in laboratory work.

\section{REFERENCES}

Blakemore, L.C., Searle, P.L. and Daly, B.K., 1987. Methods for Chemical Analysis of Soils. New Zealand Soil Bureau Scientific Report 80, Department of Scientific and Industrial Research, Lower Hutt. 103 pp.

Cambon, J.P. and Bastide, J., 1992. Chemical or microbial degradation of sulfonylureas in soil. III. Thifensulfuron-methyl. Weed Res. 32: 357-362.

James, T.K. Rahman, A. and Mortimer, J., 1989. Biological activity of DPX-L5300 in some New Zealand soils.Proc. 42nd N.Z. Weed and Pest Control Conf.: 91-94.

Lehmann, R.G., Fontaine, D.D. and Olberding, E.L., 1993. Soil degradation of flumetsulam at different temperatures in the laboratory and field. Weed Res. 33: 187-195.

Sims, G.K., Wolt, J.D., Lehmann, R.G., Anderson, J.P.E. and Torstensson, L., 1992. Bioavailability of sorbed pesticides and other xenobiotic molecules. Proc. Int. Symp. Environ. Aspects Pest. Micro.: 159-164.

Voroney, R. P., Winter, J.P. and Beyaert, R.P. (1993). Soil microbial biomass C and N. Pp 277-287. In: Soil Sampling and Methods of Analysis, M.R. Carter (Ed); Lewis Publishers, Boca Raton. 